\title{
1 Blue carbon sequestration dynamics within tropical seagrass sediments: long-term 2 incubations for changes over climatic scales
}

3 Chee Hoe Chuan ${ }^{\mathrm{A}}$ John Barry Gallagher ${ }^{\mathrm{B}}$, Swee Theng Chew ${ }^{\mathrm{A}}$ and M. Zanuri Norlaila Binti ${ }^{\mathrm{C}}$ Kinabalu, Sabah, Malaysia. Point, Tas 7004, Australia.

${ }^{\mathrm{C}}$ Centre for Marine and Coastal Studies, Universiti Sains Malaysia, 11800, Penang, Malaysia.

${ }^{\mathrm{B} C}$ Corresponding author. Email: john.barry@usm.my

Determination of blue carbon sequestration in seagrass sediments over climatic time scales (>100 years) relies on several assumptions, including no loss of particulate organic carbon (POC) after 1-2 years, tight coupling between $\mathrm{POC}$ loss and $\mathrm{CO}_{2}$ emissions, no dissolution of carbonates, and removal of the recalcitrant black carbon (BC) contribution. We tested these assumptions via 500-day anoxic decomposition and mineralisation experiment to capture centennial parameter decay dynamics from two sediment horizons robustly dated as 2 and 18 years old. No loss of BC was detected, and decay of POC was best described for both horizons by near-identical reactivity continuum models. The models predicted average losses of 49 and $51 \%$ after 100 years of burial for the surface and 20-22-cm horizons respectively. However, the loss rate of POC was far greater than the release rate of $\mathrm{CO}_{2}$, even after accounting for $\mathrm{CO}_{2}$ from particulate inorganic carbon (PIC) production, possibly as siderite. The deficit could not be attributed to dissolved organic carbon or dark $\mathrm{CO}_{2}$ fixation. Instead, evidence based on $\delta^{13} \mathrm{CO}_{2}$, acidity and lack of sulfate reduction suggested methanogenesis. The results indicated the importance of centennial losses of POC and PIC precipitation and possibly methanogenesis in estimating carbon sequestration rates.

ToC Summary. Seagrasses remove and bury $\mathrm{CO}_{2}$ as sedimentary organic matter in sufficient amounts to mitigate global warming. However, a 2-year sediment-incubation study indicated that $50 \%$ could be lost over climatic time scales, forming greenhouse gases such as $\mathrm{CO}_{2}$ and methane. This could lead to underestimated emissions within a carbon cap and trade market, if such losses are not taken into account.

C. H. Chuan et al.

Seagrass sediment decomposition and mineralisation

Additional keywords: carbonate, diagenesis, methane, pyrogenic carbon, sediment geochemistry, sediment isotope tomography.

\section{Introduction} significant global carbon (C) sink (Mcleod et al. 2011). For seagrass in particular, this service is 
Publisher: CSIRO; Journal: MF:Marine and Freshwater Research

Article Type: Research Paper; Volume: ; Issue: ; Article ID: MF19119

DOI: 10.1071/MF19119; TOC Head:

based on two separate concepts, namely, sedimentary $\mathrm{C}$ stocks and rates of sedimentary $\mathrm{C}$ sequestration. The stock- or storage-service concept, in the mitigation of greenhouse-gas emissions, is a scalar concept and conceived at the meadow scale. It has traditionally been estimated by potential $\mathrm{C}$ loss to mineralisation should it be disturbed over a climatic timescales (Pendleton et al. 2012). Climatic timescales are defined to be close toc. 100 years, over which the full impacts of feedbacks on climatic variability become evident (IPCC,2013). The depth of such disturbances, and the extent of its effect on the $\mathrm{C}$ stock, is dependent on the type of disturbance (Siikamäki et al.2013; Gallagher 2017) and is independent of the time it took the $\mathrm{C}$ to accumulate. The sediment found within seagrass beds contains a sizable detrital organic component, consisting of a mix of deposited seagrass litter, associated epiphyte and microalgal detritus, and additional inputs from adjacent land activities, fluvial deposition, and saltmarsh and mangroves (Kennedy et al. 2010). Inputs other than surface deposition have been recognised, such as seagrass root exudates. Exudates feed the rhizosphere anoxic microflora under nitrogen $(\mathrm{N})$-depleted conditions (Welsh 2000); however, how much this contributes to the sedimentary particulate organic C (POC) is still unclear, and is beyond the scope of the present study. In contrast, the C-sequestration service is a vector concept. Rates of sequestration depend on the balance between detrital production and mineralisation relative to an alternative and likely non-vegetated state (Siikamäki et al. 2013; Gallagher 2017). Non-vegetated sediments have, in general, shown increased rates of mineralisation (Kristensen et al. 1995) and mobilisation of dissolved organic C (DOC) during resuspension (Koelmans and Prevo 2003). Because this is a service in the mitigation of global warming, its extent has been traditionally estimated as the rate at which sedimentary organic mass accumulates over time scales ranging from inter-decadal to centennial (Duarte et al. 2013; Gallagher 2015), subsequently integrated across the meadow.

Notwithstanding uncertainties about the size of past meadow coverage and the amount and fate of exported litter (Gallagher 2014; Duarte and Krause-Jensen 2017), researchers are increasingly recognising that the traditional methods of calculating sedimentary $\mathrm{C}$-accumulation rates may have built-in biases (Gallagher 2015; Johannessen and Macdonald 2016; Chew and Gallagher 2018). For example, previous studies have failed to subtract allochthonous recalcitrant forms of $\mathrm{C}$ such as black or pyrogenic $\mathrm{C}$ from estimated $\mathrm{C}$ stocks. Pyrogenic $\mathrm{C}$ is produced by incomplete combustion of biomass and fossil fuels. It is considered sufficiently stable to be outside the climatic C loop (Liang et al. 2008; Wang et al. 2016), and, thus, its storage and sequestration within seagrassecosystem sediments cannot be counted as a greenhouse gas-mitigation service (Chew and Gallagher 2018). Mass-accumulation rates of POC per unit time and area, the product of sedimentation rates and POC concentrations, have assumed no significant losses after 1-2 years within their surface sediments (Cebrian 1999). The humification of seagrass, macroalgae and mangrove detritus has been shown to occur over several months after deposition, becoming more 
Publisher: CSIRO; Journal: MF:Marine and Freshwater Research

Article Type: Research Paper; Volume: ; Issue: ; Article ID: MF19119 DOI: 10.1071/MF19119; TOC Head:

recalcitrant after burial (Middelburg 1989; Burdige 2007). Further, any such losses are assumed to be tightly coupled with carbon dioxide $\left(\mathrm{CO}_{2}\right)$ emissions, ostensibly from aerobic mineralisation or sulfate reduction (Burdige 1991), whereby the release of ammonia can feed further production. Methanogenesis has been known to play a measurable role within highly organic non-vegetated coastal sediments (Boehme et al. 1996). However, long-term incubation experiments with marine non-vegetative sediments consisting of predominantly, but not exclusively, phytoplanktonic sources have suggested that POC continues to be lost within deeper and older sediments (Westrich and Berner 1984; Burdige 1991; Arndt et al. 2013; Canuel et al. 2017), with further losses of the POC fraction being transformed to a mobile DOC pool (Holmer 1996; Hee et al. 2001; Burdige et al. 2016). Furthermore, the $\mathrm{CO}_{2}$ need not be from organic mineralisation. Sulfate reduction within non-vegetated coastal sediments has been found to result in sufficient alkalisation to produce $\mathrm{CO}_{2}$ from the subsequent precipitation of calcium carbonate $\left(\mathrm{CaCO}_{3}\right)$ in the form of particulate inorganic C (PIC; Mucci et al. 2000; Rassmann et al. 2016). Should this be a phenomenon within anoxic seagrass sediments, then this apparent emission source needs to be balanced with PIC dissolution subsequent to re-alkalisation of the water column after disturbance of the non-vegetated state. This can reduce the partial pressure of carbon dioxide $\left(p \mathrm{CO}_{2}\right)$ in the water column, which ironically becomes a net $\mathrm{CO}_{2}$ sink from the atmosphere, the extent of which depends on the residence time of the water body (Howard et al. 2018).

Aims

This study aims, for the first time, to use long-term (500 days) 'open' anoxic slurry incubations of tropical seagrass-meadow sediments to (1) estimate any centennial losses of POC by capturing the rates and dynamics of POC and possibly otherwise stable black C (BC) mineralisation and decomposition within highly organic sediments, and (2) recognise the suite of chemical and geochemical processes involved. Incubation was followed by a relatively short period of aeration (30 days) to the anoxic incubation as a model for the immediate effects of disturbance on the mineralisation and decomposition of both POC and PIC. Younger (1-2 years old) surface sediments were used to compare the POC and PIC decomposition and mineralisation rates with those of deeper, older horizons. This was undertaken by fitting the time series to the most appropriate diagenetic model (Arndt et al. 2013). After sediment deposition, ages were determined with either an evaluated event or ${ }^{210} \mathrm{~Pb}$ geochronology; the model was used to extrapolate any losses over 100 years for a more considered rate of POC sequestration. The newly measured POC was then further constrained by measurements of additional diagenetic variables, namely $\mathrm{CO}_{2}$, coloured dissolved organic matter (CDOM) as a proxy for the DOC pool, ammonia as evidence of sulfate reduction and PIC, in the form of carbonate, so as to disentangle changes in $\mathrm{CO}_{2}$ from inorganic and organic dynamics. 
Publisher: CSIRO; Journal: MF:Marine and Freshwater Research

Article Type: Research Paper; Volume: ; Issue: ; Article ID: MF19119

DOI: 10.1071/MF19119; TOC Head:

\section{Materials and methods}

Study site

Two similar subtidal Enhalus sp. seagrass meadows in separate branches of the SalutMengkabong estuary were chosen for the study (Fig. 1). The region can be considered as moderately urban; it is located $20 \mathrm{~km}$ north of a city centre (Kota Kinabalu, Sabah, Malaysia) and within the penumbra of the near-annual south-western Borneo and Sumatra haze events. These events ostensibly deposit BC into the estuary from peat fires on the southern part of the island as well as from slash-and-burn land-clearing activities (Gaveau et al. 2015; Chew and Gallagher 2018). The two bays are both turbid and shallow (1-3 m) and surrounded by mangrove forests with exposed intertidal mud banks. The diurnal springs tides range ranged between 1.4 and $1.7 \mathrm{~m}$ and neaps can vary between 0.2 and $0.8 \mathrm{~m}$ (Hoque et al. 2010). One meadow, within the Salut branch, was used to collect sediments for the slurry incubations, whereas the other meadow, within the Mengkabong branch, was used to constrain the Salut meadow's geochronology. This was necessary for disentangling and identifying the likely and known regional-storm depositional events from unknown local disturbances (Gallagher and Ross 2018).

\section{Sediment collection and incubation}

The sediments for the decomposition experiment were taken in 2016 from 22 cores spaced $\sim 30$ $150 \mathrm{~m}$ apart. The cores were transported back to the laboratory under ice (ambient temperature in icebox $=10.2^{\circ} \mathrm{C}$ ), where the surface $2-\mathrm{cm}$ and $20-22-\mathrm{cm}$ horizons were extracted and pooled. The latter horizon was taken a short distance ahead of the start of a transition to a lower, more fibrous brown facies $(>26 \mathrm{~cm})$. Samples from each sediment horizon were pooled in the manner of Westrich and Berner (1984) after wet sieving (1 mm) with previously filtered boiled seawater to remove large shells, debris and benthic fauna. This was undertaken to remove the organic-matter contribution of any live fauna from anoxic detrital decay, while maintaining the natural bacterial flora present (Gontikaki et al. 2015). After this, the pooled samples were divided into four separate Mason jars under $\mathrm{N}$, and filtered boiled seawater was added to make up a $400-\mathrm{cm}^{3}$ slurry with a final water content of $81.9 \%$. Before the start of the incubation, the slurries were bubbled with $\mathrm{N}_{2}$ for $25 \mathrm{~min}$ and the anoxic status was checked (ellow Springs Instruments (YSI) Xylem-Analytics Ltd, Australia ProDSS probe) before the Mason jar lids were replaced. To ensure that the sulfate supply was not limiting sulfate reduction, additional sulfate was added in a stoichiometric proportion to the measured amount of $\mathrm{CO}_{2}$ emitted. This was undertaken after the first month and again a further three times over the course of the first 300 days of the experiment. As a further precaution, sulfide and $\mathrm{CO}_{2}$ traps were placed in the jar headspace to both inhibit and control any build-up of metabolites and to measure net accumulative mineralisation. The sulfide traps were constructed by using epoxy to fasten a 110-mm-diameter Whatman No. 1 filter paper saturated with $1 \%$ zinc acetate to the underside of each jar lid. These were strategically folded to present a 
Publisher: CSIRO; Journal: MF:Marine and Freshwater Research

Article Type: Research Paper; Volume: ; Issue: ; Article ID: MF19119

DOI: 10.1071/MF19119; TOC Head:

large total surface area and were placed alongside lead acetate paper strips to visibly detect any ongoing emissions of hydrogen sulfide $\left(\mathrm{H}_{2} \mathrm{~S}\right)$. The filter papers were refreshed with fresh solution after every sampling procedure. The $\mathrm{CO}_{2}$ traps contained 2-3 $\mathrm{g}$ of dried high absorbance-capacity soda lime (Dharmakeerthi et al. 2015) placed in $15-\mathrm{cm}^{3}$ polypropylene centrifuge tubes. The tubes were open to the headspace and were replaced after each sampling time for further gravimetric measurements of $\mathrm{CO}_{2}$ accumulation rates. An additional set of soda lime traps was also placed in four Mason jars filled with filtered boiled seawater $\left(400 \mathrm{~cm}^{3}\right)$, which were added to the incubation cohort as $\mathrm{CO}_{2}$ procedural blanks (Keith and Wong 2006).

The Mason jar sediment slurries and blanks were all incubated at $30^{\circ} \mathrm{C}$ in a constant-temperature room in the dark (covered in aluminium foil as a precaution against disturbance). The slurries were sampled after 7, 21, 42, 63, 105, 140, 175, 210, 308, 365, 400, 420, 470 and 500 days for POC, $\mathrm{CDOM}$, ammonia, $\mathrm{pH}$ and $\mathrm{CO}_{2}$. A Day 0 sample for $\mathrm{POC}$ was added after the first year. These were taken from the remaining pooled sediments (stored at $-20^{\circ} \mathrm{C}$ ) and replicated with sediments from corresponding horizons within the sediment core used for the meadow's geochronology. At selected times, samples were taken for $\delta^{13} \mathrm{C}_{\mathrm{POC}}, \mathrm{C}: \mathrm{N}_{\mathrm{POC}}$ ratios for both horizons and $\delta^{13} \mathrm{CO}_{2}$ trapped by the soda lime for the surface sediments.

After 500 days, additional aerated filtered seawater was added to the jars to bring the volume back to $400 \mathrm{~cm}^{3}$ and the $\mathrm{pH}$ was adjusted to 8.5 with sodium hydroxide ( $\mathrm{NaOH}$; Analar). The slurries were again kept in the dark at $30^{\circ} \mathrm{C}$ and aerated for 30 days. To remove any possible organic and $\mathrm{BC}$ aerosols that might contaminate the slurry, the air was first passed through highefficiency particulate arrestance (HEPA) filters. The filters also supported a coarse polyester mat impregnated with charcoal. The $\mathrm{pH}$ of the slurry was adjusted every few days to maintain acidity between $\mathrm{pH} 7$ and 8, and distilled water was added to replace any evaporative loss (Westrich and Berner 1984).

\section{Sampling and analysis protocols}

The Mason jars were reopened under a $\mathrm{N}_{2}$ atmosphere and the $\mathrm{pH}$ of the slurry water was measured after the sediment had settled (ATC portable PH-107 (PH-009) Shanghai Longway Optical Instruments), and their anoxic status was checked (YSI ProDSS). For sampling of the slurry, a cut-off syringe was used to extract $10 \mathrm{~cm}^{3}$ of slurry after thorough mixing; the subsamples were placed in $15-\mathrm{cm}^{3}$ polypropylene centrifuge tubes and frozen at $-20^{\circ} \mathrm{C}$ before analysis. The remaining slurry was then bubbled with $\mathrm{N}_{2}$ for 2 min as a precaution to maintain the anoxic conditions within the jar. The lids of the jars were then resealed under $\mathrm{N}_{2}$ after the soda lime traps were removed, capped and replaced with identical traps. The traps were immediately oven-dried and reweighed after first softly cleaning the surface of the centrifuge tubes of any accumulated red biofilm, and $\mathrm{CO}_{2}$ was determined gravimetrically (Keith and Wong 2006). Blanks indicated no 
Publisher: CSIRO; Journal: MF:Marine and Freshwater Research

Article Type: Research Paper; Volume: ; Issue: ; Article ID: MF19119

DOI: 10.1071/MF19119; TOC Head:

significant leakage of air into the Mason jars and typically showed an increase in weight of $\sim 0.0332 \mathrm{~g}$ (standard error (s.e.) $=0.014, n=4$ ), a value that is $68 \%$ less than the weight increase from the traps in the jars containing slurry samples.

After thawing, the slurry samples were centrifuged at $2500 \mathrm{~g}$ for $20 \mathrm{~min}$ at ambient temperature $\left(\sim 25^{\circ} \mathrm{C}\right)$ to separate the pore water for measurements of $\mathrm{CDOM}_{440 \mathrm{~nm}}$ (Harvey et al. 2015), ammonia (Strickland and Parsons 1968) and salinity (refractometer). The remaining sediment plug was then dried at $105^{\circ} \mathrm{C}$ and the amount of water and sediment was noted to calculate the amount remaining in the mason jars for $\mathrm{CO}_{2}$ accumulation as dry weight of sediment after correcting for salinity (Lavelle and Massoth 1985). Particulate organic matter (POM), PIC and black organic matter (BOM) from the dried sediment slug was measured gravimetrically by loss on ignition ( $\mathrm{LOI}_{0.45 \mathrm{~g}}$ ) in a laboratory furnace (Carbolite CWF 1.8 L, Carbolite-Gero Ltd (UK); Heiri et al. 2001; Chew and Gallagher 2018). Additional inter-batch corrections resulting from possible furnace aging and procedural handling differences were performed using in-house local sediment standards taken from the middle of the cores $(n=5)$ and randomly placed within the furnace. Standards were previously dried $\left(60^{\circ} \mathrm{C}\right)$ and stored frozen $\left(-20^{\circ} \mathrm{C}\right)$. All POM and BOM values were then converted to $\mathrm{C}$ content -using a local calibration regression. The regression was constructed previously from sediments taken from Salut-Mengkabong seagrass and mangroves (Chew and Gallagher 2018) by using the same furnace and in-house sediment standards. A coefficient of 0.273 used to transform the $\mathrm{LOI}_{550-950^{\circ} \mathrm{C}}$ to $\mathrm{PIC}$, by assuming the carbonate species to be calcium salt (Santisteban et al. 2004). However, it should be noted that a later analysis of the data suggested that the increase in carbonate may have been from ferrous salt. Until certainty is established, in both the form of thermal decomposition equation during the analysis and identity of the salt, all PIC contents are reported as $\mathrm{CaCO}_{3}$. All measurements are presented, except for $\mathrm{CDOM}_{440 \mathrm{~nm}}$, in molar units for stoichiometric comparisons. $\mathrm{CDOM}_{440 \mathrm{~nm}}$ was converted to DOC to give the organic dissolved pool dynamic an order of magnitude significance with other $\mathrm{C}$ variables. As far as we are aware, the calibration used for the conversion is the only one available for 440-nm determinations for an estuarine system (Harvey et al. 2015). The dataset is provided in the Table/Fig. Sxx, available as Supplementary material to this paper should it be necessary for readers to rework the $\mathrm{CDOM}_{440 \mathrm{~nm}}$ and PIC content in light of new information.

Analyses of stable POC isotopes of $\delta^{13} \mathrm{C}$ and their $\mathrm{C}: \mathrm{N}$ ratios were performed on the two horizons across separate mason jars at selected times (Days 0 and 210). Before analysis, the samples were dried and vacuum sealed and sent to the Canadian Rivers Institute, University of New Brunswick Nature Laboratory (SINLAB). Re-drying after acidification (10\% $\mathrm{HCl}$, Analar) to remove PIC was performed before analysis at the institute. No isotope or element analysis was undertaken for the local source materials, which would typically be required for an estimation of their relative proportions. Nevertheless, estimations were gauged on the average ${ }^{13} \mathrm{C}_{\mathrm{POC}}$ and $\mathrm{N}: \mathrm{C}$ 
Publisher: CSIRO; Journal: MF:Marine and Freshwater Research

Article Type: Research Paper; Volume: ; Issue: ; Article ID: MF19119

DOI: 10.1071/MF19119; TOC Head:

endpoint signatures of seagrass, mangrove leaves and suspended particulate matter, using a model constructed for several tropical lagoons (Gonneea et al. 2004; Chen et al. 2017). In addition, stable isotopes of $\delta^{13} \mathrm{CO}_{2}$ trapped by the soda lime (Days 7, 210, 308 and 500) were measured from a surface-horizon mason jar replicate. The jar was selected at random, and the analysis at the Central Science laboratory was performed by mixing ground samples and subsamples under an Argon (Ar) atmosphere and placing $2.5 \mathrm{mg}$ into pre-flushed (Ar) vacutainers. The $\mathrm{CO}_{2}$ was released after dissolving the powder with pure phosphoric acid before injection. Handling errors were tested on one sample (mean, -19.78 ; s.e. $\pm 0.98, n=4$ ). Note that limited resources precluded any additional isotope analysis of either sediments or soda lime.

Sediment cores for the geochronology were collected using a sliding hammer Kajak corer (UWITEC, Austria) equipped with a 6-cm internal-diameter polycarbonate core tube; the sediment-water interface was stabilised with a porous polyurethane foam plug. The core was transported vertically under ice to the laboratory for push extraction. Water content, bulk density, porewater salinity and loss on ignition at $550^{\circ} \mathrm{C}$ and $950^{\circ} \mathrm{C}$ were measured every $2 \mathrm{~cm}$ (Gallagher and Ross 2018). The remaining sediment for each horizon was used to determine particle size (laser diffraction, model: 220 Type B, LISST-Portable XR, Sequoia Scientific (Australia) ); after drying $\left(50^{\circ} \mathrm{C}\right)$ and storage for 3 months, ${ }^{210} \mathrm{~Pb},{ }^{226} \mathrm{Ra}$ and ${ }^{137} \mathrm{Cs}$ radionuclide analysis was performed using gamma spectroscopy at the Malaysian Institute of Nuclear Technology (Bangi, Selangor).

\section{Decomposition model}

The reactivity-continuum (RC) model was chosen to model the POC decomposition time series (Boudreau 1991; Arndt et al. 2013; Mostovaya et al. 2017). Exploratory analysis indicated that this gave the best fit and was the most parsimonious descriptor of the POC dynamics over single and multi G models (Arndt et al. 2013). The model fits a continuous distribution of organic matter decomposition, from labile to increasingly recalcitrant, and was calculated as follows:

$$
\frac{P O C_{t}}{P O C_{0}}=\left(\frac{a}{a+t}\right)^{v}
$$

where $a$ is the apparent age of the organic mixture (years) within the deposit, as a measure of its degradability relative to an apparent age at the time of deposition. The exponent $v$ is the gamma distribution coefficient, which describes the labile-recalcitrant distribution and dominance (1-0 respectively) of the organic mix of the sediment horizon. Taken together, the initial first-order decomposition coefficient, $k_{0}$, is defined as $v / a$, which becomes increasingly recalcitrant with incubation and Burial time $t$. The parameter solutions were calculated iteratively, using a nonlinear least-square parameter estimation within the software platform SigmaPlot ${ }^{\mathrm{TM}}$ 12.0. It should be noted that there is a rival continuous diagenetic model. The model, ostensibly constructed within phytoplanktonic and bacteria-dominated sediments, uses a power function to describe how organic matter becomes increasingly recalcitrant over apparent time (Middelburg 1989). Although 
Publisher: CSIRO; Journal: MF:Marine and Freshwater Research

Article Type: Research Paper; Volume: ; Issue: ; Article ID: MF19119

DOI: 10.1071/MF19119; TOC Head: the two models are equivalent mathematically (Tarutis 1993) when applied within closed systems such as jars (i.e. no sediment accretion), the mix of seagrass litter, microalgae and mangroves in the sediment (see Results), all with very different intrinsic reactivities (Middelburg 1989; Kristensen 1994), would seem more aligned with an RC explanation than a relatively less parsimonious power model as a sum of differing degrees of aging across different organic sources.

\section{Geochronology}

Sediment isotope tomography (SIT) was used to model a continuous ${ }^{210} \mathrm{~Pb}$ geochronology down the uninterrupted depositional regions of the sediment core (Gallagher and Ross 2018). The model describes how the ${ }^{210} \mathrm{~Pb}$ activity of sedimentary horizons can be fitted to a function that includes the changes in the ${ }^{210} \mathrm{~Pb}$ flux and sedimentation velocity as the ${ }^{210} \mathrm{~Pb}$ decays over time (Carroll et al. 1999). The algorithm employs a parsimonious inverse solution to best simulate the ${ }^{210} \mathrm{~Pb}$ profile by solving for the model parameters for maximum disentanglement of the flux and sedimentation velocity terms (Liu et al. 1991). Further constraints and evaluations of solutions can be made by the presence of known events (Carroll et al. 1999). Such events are traditionally peaks or horizons of ${ }^{137} \mathrm{Cs}$ from atomic fallout within baseline sediments, and depositional facies characteristic of surrounding material brought in by storms, earthquakes, floods or tsunamis.

Supporting data, additional figures cited, and method details can be found in Supplementary material to this paper.

\section{Results}

\section{Sediment-core descriptions}

The first $23 \mathrm{~cm}$ of the Salut and $25 \mathrm{~cm}$ of the Mengkabong meadows were visibly muddy (black), with no evidence of bioturbation. Below the $23-\mathrm{cm}$ and $25-\mathrm{cm}$ horizons, the character of the sediment visibly changed to a coarser mixture of more compact light and dark brown sediments containing a plethora of shell and mangrove wood debris (refer to Fig. S2). No sulfide could be detected by smell or with lead acetate strips left in the sediment for a minute while they were extruded into receiving tubes before separation.

\section{Sediment-horizon organic composition}

The ${ }^{13} \mathrm{C}_{\mathrm{POC}}$ and their $\mathrm{N}$ : $\mathrm{C}$ ratios taken through the incubation did not appear to change and the two horizons exhibited near identical signatures (Table 1). These signatures converged even further when the effects of diagenetic transformations were considered (Gälman et al. 2008; Gälman et al. 2009). Interestingly, it was found that seagrass litter was likely to be a minor component ( 5\%). The remaining components of surface-suspended matter, ostensibly microalgae, and mangrove sources made up the remaining $25 \%$ and $70 \%$ respectively (refer to Supplementary material), in agreement with other ecosystems in the region (Chen et al. 2017). 


\section{Geochronology}

Although the depths of the storm facies were similar, it was clear from the ${ }^{210} \mathrm{~Pb}$-activity profiles that the sedimentation dynamics within the baseline sediments were very different. The Salut meadow, an embayment isolated at the head of the branch and fed by a rivulet, supported peaks in activity at $\sim 10 \mathrm{~cm}$ (Fig. 2), in contrast to a general decay in ${ }^{210} \mathrm{~Pb}$ activity from the surface of the Mengkabong meadow (Fig. 2), an embayment isolated from the main branch. The difference in dynamics was also highlighted in the inability to detect any ${ }^{137} \mathrm{Cs}$ activity from atomic fallout events within Salut sediments, which were evident as significant ${ }^{137} \mathrm{Cs}$ activity between $5 \mathrm{~cm}$ and $13 \mathrm{~cm}$, peaking at $5 \mathrm{~cm}$ down the Mengkabong meadow core. This relatively shallow signal is consistent with blow back of fallout from the 2011 Fukushima Daiichi nuclear accident (Kaeriyama 2017).

When the SIT solution for the Mengkabong system was constrained by the timing of the Fukushima fallout, the age of the depositional event was estimated as $\sim$ mid-1990s. The only recent weather event of note was from the passage of tropical storm Greg (December 1996). The storm is regarded as a once-in-400-years occurrence for this region, which is commonly known as 'the land below the wind' because of its location south of the influence of the typhoon belt. The 1996, storm triggered floods that severely affected the western coast of the state (Abdullah and Tussin 2014), and a local resident shared his experience as a witness to a coastal surge of $\sim 4 \mathrm{~m}$ within the adjacent mangrove forests (Mohammad Asri bin Mohammad Suari, pers. comm.). With the confirmation that the depositional event was likely to be tropical storm Greg, the SIT model now adds constraints for the Salut meadow baseline sediments of age no older than 1996. On the basis of these solutions, the origin of the very different ${ }^{210} \mathrm{~Pb}$ dynamics becomes apparent. In Salut, both the flux of the excess ${ }^{210} \mathrm{~Pb}$ activity and the sedimentation rates of the meadow fell over time. In Mengkabong, rates of sedimentation and ${ }^{210} \mathrm{~Pb}$ activities remained relatively constant $\left(220 \mathrm{~g} \mathrm{~m}^{-2}\right.$ per year, Fig. 2) and were interrupted only by an increase in excess ${ }^{210} \mathrm{~Pb}$ activity consistent with shoreline development during a peak in annual rainfall ( 2005, unpubl. data Swee Theng Chew ). These show relatively high sequestration rates near the top of the range, even before any correction for loss over time (Fig. 2).

\section{Incubation experiment}

Throughout the incubation experiment, the $\mathrm{pH}$ of both surface sediments and sediments taken from 20-22 cm became increasingly acidic over time (Fig. 3). The older sediments taken from 20 $22 \mathrm{~cm}$ were more acidic and remained invariant and acidic. Surface-sediment slurries, in contrast, were initially less acidic; however, their acidity increased over time, reaching an asymptote after 300 days equal to that of the older sediment slurry. The experiment failed to detect the presence of $\mathrm{H}_{2} \mathrm{~S}$ within the jar headspace (no blackening of the lead acetate strips) that would infer ongoing sulfate reduction. 
Publisher: CSIRO; Journal: MF:Marine and Freshwater Research

Article Type: Research Paper; Volume: ; Issue: ; Article ID: MF19119

DOI: 10.1071/MF19119; TOC Head:

Even though the initial BC represented a modest fraction of the POC ( 0.079 and $0.067 \mathrm{~mol}$ per $100 \mathrm{~g}$ or 11-13\%), its influence on the POC dynamics was not apparent because there was no significant decay in the $\mathrm{BC}$ content over the 500 days, and $\mathrm{RC}$ solutions with the time series failed to converge. The anoxic decay of POC for the surface- and older 20-22 cm-horizon sediments fitted the RC model well, and the separation of the terms was within acceptable limits (Fig. 4). Surface-sediment POC content was greater than that of sediments taken from 20-22 cm. However, we found no significant difference in their RC decay and apparent age parameters for the decomposable fraction (Fig. 5), despite different interdecadal depositional ages (18 years). Projections suggested that both horizons would have lost close to $30 \%$ of their POC content within the first several years $(6-7)^{1}$. Nevertheless, the overarching dynamics were such that both horizons converged to losses of $\sim 49$ and $51 \%$ after 100 years of burial.

In contrast to POC, the dynamics of PIC, DOC and ammonia $\left(\mathrm{NH}_{3}\right)$ were not continuous. After $\sim 300$ days, the carbonate content started to increase for both sediment horizons and appeared to move towards an asymptote. This was accompanied by an increase in $\mathrm{NH}_{3}$ and a decrease in DOC content (Fig. 3) after the $\mathrm{NH}_{3}$ content had first fallen and the DOC content increased (Fig. 3). Pools of DOC and $\mathrm{NH}_{3}$ were notably an order of magnitude smaller than that of POC. Only the cumulative $\mathrm{CO}_{2}$, after correction for PIC generation after the 300 days, showed steady-state dynamics that slowed towards an asymptote (Fig. 6). However, there appeared to be a notable deficit in the amount of $\mathrm{CO}_{2}$ emitted for the amount of POC decomposed, in particular, for the deeper, older sediment horizon. Furthermore, the $\delta^{13} \mathrm{C}_{\mathrm{POC}}$ isotopic signatures were not coupled to each other. The $\delta^{13} \mathrm{CO}_{2}$ values extracted from the soda lime were both relatively constant and very much heavier than those extracted from the POC mixture. The $\delta^{13} \mathrm{CO}_{2}$ was measured as $-19.78 \pm$ $1.95(n=4)$ at Day 7, $-17.74(n=1)$ at Day 189, $-19.30(n=1)$ at Day 308 and $-18.56(n=1)$ at Day 500, the end of the incubation experiment. Meanwhile, at the same time, the $\mathrm{NH}_{3}, \mathrm{DOC}$ and PIC contents in the sediment slurry remained relatively constant up until about Day 365, when a change in trend was observed (Fig. 3). From Day 365 until the end of the incubation experiment, both PIC and $\mathrm{NH}_{3}$ concentrations in the surface-sediment slurry increased, with an increase of $46.48 \%$ (s.e. $=3.91, n=4$ ) in PIC and $60.86 \%$ (s.e. $=1.57, n=4$ ) in $\mathrm{NH}_{3}$ concentrations, whereas DOC concentrations dropped by as much as $73.77 \%$ (s.e. $=8.75, n=4$ ) over the same period of time. Meanwhile, for the sediment slurry taken from 20-22 cm, $\mathrm{PIC}$ and $\mathrm{NH}_{3}$ concentrations increased by $50.57 \%$ (s.e. $=1.44, n=4$ ) and $73.19 \%$ (s.e. $=2.17, n=4$ ) respectively, whereas DOC concentrations dropped by $28.44 \%$ (s.e. $=4.89, n=4$ ).

\section{Aeration incubation}

The short aeration pulse over 30 days after the completion of the 500-day anoxic incubation showed a large decrease in POC $(18.86 \%$, s.e. $=4.09, n=4$ for surface sediments; $16.99 \%$, s.e. $=$ $5.04, n=4$ for sediments from 20-22 cm), outside that of the parameters of the anoxic 
Publisher: CSIRO; Journal: MF:Marine and Freshwater Research

Article Type: Research Paper; Volume: ; Issue: ; Article ID: MF19119

DOI: 10.1071/MF19119; TOC Head:

354 mineralisation models (Fig. 4). This increase in decomposition was also in line with a

355 disproportionate increase in DOC over the anoxic mineralisation, confirming that, for both

356 horizons, organic aging had little effect on the recalcitrance of the buried POC.

\section{Discussion}

\section{Decomposition}

Assuming the incubation was sufficiently long to capture interdecadal decay parameters, it appears that POC deposited, on average within 1-2 years of deposition may suffer significant losses over climatic scales (49-51\%). However, we must suggest caution in applying the surfacehorizon extrapolations as a generalisation to seagrass beds in other locales, as such sediments will inevitably change their redox status from an aerobic- to an anaerobic-dominated form of mineralisation. Aerobic mineralisation is clearly the more rapid of the two, the result of greater efficiency in the mineralisation of the recalcitrant fractions (Kristensen et al. 1995). As well as changing redox conditions, the nature of the organic mixture will likely affect the decay parameters of the RC model. Clearly, the remaining half of the organic C, a seemingly recalcitrant fraction, is more than can be accounted for by the $<10 \%$ contribution of the $\mathrm{BC}$ alone. It is also unlikely, in this case, that any presence of phytolith-occluded $\mathrm{C}$ was responsible, given that the $\mathrm{BC}$ methodology may have inadvertently included this form (Chew and Gallagher 2018). What remains is up to speculation; it may consist of bacterial necromass (Burdige 2007) and, an increasingly important vector, especially within Southeast Asian coastal ecosystems, namely microplastics (Nor and Obbard 2014; Li et al. 2019). Although microplastics have turnover times of over 1000 years (Gewert et al. 2015), their amounts as C within soils and sediments remain largely unknown. Some values have been estimated for terrestrial soils (Rillig 2018), ranging from $0.1-5 \%$ of POC for pristine environs to as much as $6.7 \%$ by soil weight.

Whatever value the overall decay parameters may take over space or time, it remains puzzling that we found little difference in the POC decomposition-model parameters between the surface and the deeper sediment horizons. This was not apparent in coastal non-vegetative sediments, which are dominated by more labile phytoplanktonic organic sources (Burdige 1991; Zimmerman and Canuel 2002). This can be explained by the following two possible theories: either the sediments in these types of meadows were well mixed, which is unlikely given the presence of ${ }^{137} \mathrm{Cs}$ peaks and ${ }^{210} \mathrm{~Pb}$ decay series, or the stable-isotope signatures and recalcitrance are not covariant down the sediment columns. For the latter to be consistent, mangrove sources would need to balance an increase in recalcitrance between or within other organic sources because they are buried over time. In essence, a mix of the reactivity continuum and power models would best describe this. However, it cannot be discounted that changes in physical protection and benthic consumption parameters may also play some role (Arndt et al. 2013). Indeed, it is this sedimentary 
Publisher: CSIRO; Journal: MF:Marine and Freshwater Research

Article Type: Research Paper; Volume: ; Issue: ; Article ID: MF19119

DOI: 10.1071/MF19119; TOC Head:

protection component that will likely reduce the generality of the result across meadows. In the more exposed and turbulent meadows, seagrass sediments are composed of larger, sandier particles (Gallagher et al. 2019). Such particles lack the necessary cohesiveness, surface area, and fine pore structures required to exclude bacterial influence (Burdige 2007). Furthermore, no account of the role of fauna reworking between surface oxic and surface anoxic sediments was found within the sediments collected. We found no standout evidence of burrows from our multiple core collections, and such reworking can only enhance mineralisation (Burdige 2007). Nevertheless, if prevalent, this would lead to an even larger bias in sediment sequestration assumption than what the present study suggests.

\section{Diagenesis and the coupling between $\mathrm{CO}_{2}$ and decomposition}

The mineralisation and decomposition series have several notable features. These are seemingly punctuated dynamics of carbonate, $\mathrm{NH}_{3}$ and DOC, the $\mathrm{CO}_{2}$ deficits with $\mathrm{POC}$ decomposition, and the notably heavier ${ }^{13} \mathrm{CO}_{2}$ signature over that of ${ }^{13} \mathrm{C}_{\mathrm{POC}}$. These dynamics suggest that the incubation experiment was not at a steady-state because different diagenetic processes switched on and off. How this affects the decomposition-model parameters is uncertain, but it is unlikely that the result is an underestimate, given that the observed diagenetic switches are likely to reflect a resource limitation that the incubation failed to supply. Nevertheless, this limitation is common to any natural perturbation experiment attempting to discover what is possible under a different set of conditions than that which may be encountered in other systems.

Within the limits of our monitored variables, the results imply that the initial fall in $\mathrm{NH}_{3}$ content under dark anoxic conditions is synonymous with coupled dissimilatory nitrate reduction (DNRA) and denitrification by anammox autotrophic $\mathrm{CO}_{2}$ fixation ( $\mathrm{Ni}$ and Zhang 2013). Indeed, recent work has also shown an unexpectedly high degree of anammox and DNRA in the upper muddy seagrass sediments of a subtropical lagoon (Salk et al. 2017). Nevertheless, the relatively small changes in $\mathrm{NH}_{3}$ indicate that any dark $\mathrm{CO}_{2}$ fixation would not have affected the overall $\mathrm{CO}_{2}$ dynamics, even after considering a stoichiometry of $\mathrm{C}: \mathrm{NH}_{3}$ of $15: 1$ (Koeve and Kähler 2010).

However, it could be argued that the production of archaeal necromass may have contributed to an increasingly recalcitrant pool of POC over time (Burdige 2007); the extent to which this would contribute to the decomposition dynamics would depend, in part, on the supply of nitrate for coupled DNRA. A reduction in the supply of nitrates may perhaps be responsible for a change to another mineralisation process responsible for the increase in both $\mathrm{NH}_{3}$ and PIC after 300 days.

Anoxic PIC and $\mathrm{NH}_{3}$ production within marine coastal sediment, although consistent with sulfate reduction (Burdige 1991; Mucci et al. 2000), is also inconsistent with several sedimentary parameters and observations. First, we could not detect any $\mathrm{H}_{2} \mathrm{~S}$ produced within the Mason jar headspace throughout the incubation period. Second, molar $\mathrm{NH}_{3}: \mathrm{CO}_{2}$ ratios were clearly an order 
Publisher: CSIRO; Journal: MF:Marine and Freshwater Research

Article Type: Research Paper; Volume: ; Issue: ; Article ID: MF19119

DOI: 10.1071/MF19119; TOC Head:

of $10^{3}$ larger than those found for marine sediments dominated by sulfate reduction (Burdige 1991). What is not clear are the reasons for the increase in PIC, of sufficient amounts to affect the $\mathrm{CO}_{2}$ dynamics. Nevertheless, the lack of evidence for significant levels of sulfate reduction and alkalinisation points to another type of mineralisation, one that can support a suitable acidic microenvironment. Recently, it has been demonstrated that an iron-reducing bacterium can precipitate siderite $\left(\mathrm{FeCO}_{3}\right)$ within acidic sediments at ambient temperatures $\left(30^{\circ} \mathrm{C}\right)$. It was suggested that alkalinisation at the cell walls was induced mainly by its production of $\mathrm{NH}_{3}$. Indeed, the dynamics of the parameters measured herein fall within the scientific justification of inference to the best explanation (Lipton 2000). The sediments were acidic and there was a parallel rise in $\mathrm{NH}_{3}$ production with PIC outside the stoichiometry of sulfate reduction. Furthermore, additional analysis of selected remaining sediment samples retained throughout the incubation experiment indicated that the total iron content was sufficient to support siderite formation $\left(0.051 \mathrm{~mol} 100 \mathrm{~g}^{-1}\right.$, s.d. $=0.0064, n=60$; see Table/Fig. Sxxxx), but only to levels to which the carbonate appears to be reaching an asymptote $\left(\sim 0.15 \mathrm{~mol} 100 \mathrm{~g}^{-1}\right.$, Fig. 3).

However, what is clear is that the overall $\mathrm{CO}_{2}$ dynamics observed fall well short of accounting for the continued loss of POC, irrespective of PIC and DOC. By itself, this implies that there must be another mineralisation product. As far as we are aware, methane $\left(\mathrm{CH}_{4}\right)$ formed from methanogenesis is the remaining alternative. Methanogenesis would result in the release of both $\mathrm{CO}_{2}$ and $\mathrm{CH}_{4}$, within its own sedimentary niche, where any iron reducers cannot directly compete (Bray et al. 2017). Although we did not measure $\mathrm{CH}_{4}$ during this incubation, the supposition is supported by the relatively constant ${ }^{13} \mathrm{C}_{\mathrm{POC}}$ values and considerably heavier ${ }^{13} \mathrm{CO}_{2}$ ratios of it mineralised gas, trapped on the soda lime, over the incubation (Table 1). Such patterns have also been found for highly organic coastal marine sediments where a considerably lighter ${ }^{13} \mathrm{CH}_{4}$ ( $\sim 58.9 \%$ ) balances out the heavier ${ }^{13} \mathrm{CO}_{2}(\sim 19.2 \%)$ fraction, to maintain a constant heavy source of ${ }^{13} \mathrm{C}_{\mathrm{POC}}$ over time (Boehme et al. 1996). Why methanogens should dominate mineralisation over sulfate reduction is not clear. Perhaps it is due to the high acidity of sediments seemingly supplied from the adjacent mangrove mudflats (Marchand et al. 2004) and iron-reducing bacteria

\section{(Koschorreck 2008).}

\section{Conclusions}

The incubation experiment appears to capture the long-term decomposition parameters for POC. The RC model seems to indicate that current estimates of $\mathrm{C}$ sequestration may be significantly overestimated, in this case, by $\sim 50 \%$, unless corrections can be made for loss over centennial time scales. More information is needed across different sedimentary environs covariant with tropical species and sources of organic C (Gallagher et al. 2019). Furthermore, much remains to be investigated on the coupling of POC losses to greenhouse-gas emissions that have different atmospheric warming effects and the roles of processes post-disposition, such as dark $\mathrm{CO}_{2}$ fixation 
Publisher: CSIRO; Journal: MF:Marine and Freshwater Research

Article Type: Research Paper; Volume: ; Issue: ; Article ID: MF19119

DOI: 10.1071/MF19119; TOC Head:

and carbonate formation on net $\mathrm{CO}_{2}$ emissions. Without certainty in both the estimates and the conceptual model, there will not be sufficient certainty in the estimates of $\mathrm{C}$ storage and sequestration services rendered by seagrass ecosystems for use in cap-and-trade $\mathrm{C}$ markets to embrace these ecosystems as part of a solution to climate change.

\section{Author contributions}

CHC and JBG assisted in fieldwork and design of equipment and analysis of the iron content. $\mathrm{CHC}$ conducted the incubation experiment and the remaining variables, created the figures and tables, compiled the supplementary material and the statistical analyses within the tables, and contributed to the modelling. JBG was responsible for the concept, the final modelling solution and led the writing of the manuscript. STC collected cores and performed the SIT ${ }^{210} \mathrm{~Pb}$ event geochronology under supervision from JBG. NMZ provided the statement on recalcitrant carbon in the form of microplastics found in the discussion. All authors approved the final version of the manuscript and agree to be accountable for all aspects of the manuscript.

\section{Conflicts of interest}

The authors declare that they have no conflicts of interest.

\section{Declaration of funding}

This research was funded in part by the Malaysian Ministry of Science Technology and Innovation (FRG0424-SG-1/2015), which funded the stable isotope analysis and the rental of the boat used in the collection of the sample cores.

\section{Acknowledgements}

Our thanks go to our boatman Awang Azmee and Michael Yap Tzuen-Kiat for help in collection and analysis of the samples.

\section{References}

<eref>Abdullah, M. H., and Tussin, A. M. (2014). Tropical cyclone, rough seas and severe weather monitoring and early warning system in Malaysia. Available at https://www.jma.go.jp/jma/jma-eng/jmacenter/rsmc-hp-pubeg/2014_Effective_TC_Warning/presentation/11_March/country_report/Country_Report_Malaysia.pdf</ eref>

<jrn>Arndt, S., Jørgensen, B. B., LaRowe, D. E., Middelburg, J. J., Pancost, R. D., and Regnier, P. (2013). Quantifying the degradation of organic matter in marine sediments: a review and synthesis. Earth-Science Reviews 123, 53-86. doi:10.1016/j.earscirev.2013.02.008</jrn>

$<$ jrn>Boehme, S. E., Blair, N. E., Chanton, J. P., and Martens, C. S. (1996). A mass balance of 13C and 12C in an organic-rich methane-producing marine sediment. Geochimica et Cosmochimica Acta 60(20), 38353848. doi:10.1016/0016-7037(96)00204-9</jrn> 
Publisher: CSIRO; Journal: MF:Marine and Freshwater Research

Article Type: Research Paper; Volume: ; Issue: ; Article ID: MF19119

DOI: 10.1071/MF19119; TOC Head:

$<j r n>$ Boudreau, B. (1991). On a reactive continuum representation of organic matter diagenesis. American Journal of Science 291, 507-538. doi:10.2475/ajs.291.5.507</jrn>

<jrn>Bray, M. S., Wu, J., Reed, B. C., Kretz, C. B., Belli, K. M., Simister, R. L., Henny, C., Stewart, F. J., DiChristina, T. J., Brandes, J. A., Fowle, D. A., Crowe, S. A., and Glass, J. B. (2017). Shifting microbial communities sustain multiyear iron reduction and methanogenesis in ferruginous sediment incubations. Geobiology 15(5), 678-689. doi:10.1111/gbi.12239</jrn>

<jrn>Burdige, D. J. (1991). The kinetics of organic matter mineralization in anoxic marine sediments. Journal of Marine Research 49(4), 727-761. doi:10.1357/002224091784995710</jrn>

<jrn>Burdige, D. J. (2007). Preservation of organic matter in marine sediments: controls, mechanisms, and an imbalance in sediment organic carbon budgets? Chemical Reviews 107(2), 467-485. doi:10.1021/cr050347q</jrn>

<jrn>Burdige, D. J., Komada, T., Magen, C., and Chanton, J. P. (2016). Modeling studies of dissolved organic matter cycling in Santa Barbara Basin (CA, USA) sediments. Geochimica et Cosmochimica Acta 195, 100-119. doi:10.1016/j.gca.2016.09.007</jrn>

<edb>Canuel, E. A., Brush, G. S., Cronin, T. M., Lockwood, R., and Zimmerman, A. R. (2017).

Paleoecology studies in Chesapeake Bay: a model system for understanding interactions between climate, anthropogenic activities and the environment. In 'Applications of Paleoenvironmental Techniques in Estuarine Studies’.pp. 495-527. (Springer: Netherlands, Dordrecht)</edb>

<jrn>Carroll, J., Lerche, I., Abraham, J. D., and Cisar, D. J. (1999). Sediment ages and flux variations from depth profiles of ${ }^{210} \mathrm{~Pb}$ : lake and marine examples. Applied Radiation and Isotopes 50(4), 793-804. doi:10.1016/S0969-8043(98)00099-2</jrn>

$<j r n>$ Cebrian, J. (1999). Patterns in the fate of production in plant communities. American Naturalist 154(4), 449-468. doi:10.1086/303244</jrn>

<jrn>Chen, G., Azkab, M. H., Chmura, G. L., Chen, S., Sastrosuwondo, P., Ma, Z., Dharmawan, I. W. E., Yin, X., and Chen, B. (2017). Mangroves as a major source of soil carbon storage in adjacent seagrass meadows. Scientific Reports 7, 42406. doi:10.1038/srep42406</jrn>

$<$ jrn>Chew, S. T., and Gallagher, J. B. (2018). Accounting for black carbon lowers estimates of blue carbon storage services. Scientific Reports 8(1), 2553. doi:10.1038/s41598-018-20644-2</jrn>

<bok> IPCC, 2013: Climate Change 2013: The Physical Science Basis. Contribution of Working Group I to the Fifth Assessment Report of the Intergovernmental Panel on Climate Change [Stocker, T.F., D. Qin, G.-K. Plattner, M. Tignor, S.K. Allen, J. Boschung, A. Nauels, Y. Xia, V. Bex and P.M. Midgley (eds.)]. Cambridge University Press, Cambridge, United Kingdom and New York, NY, USA, pp 119-158.

<jrn>Dharmakeerthi, R.S., Hanley, K., Whitman, T., Woolf, D., and Lehmann, J. (2015) Organic carbon dynamics in soils with pyrogenic organic matter that received plant residue additions over seven years. Soil Biology and Biochemistry 88, 268-274. doi:10.1016/j.soilbio.2015.06.003 </jrn> 
Publisher: CSIRO; Journal: MF:Marine and Freshwater Research

Article Type: Research Paper; Volume: ; Issue: ; Article ID: MF19119 DOI: 10.1071/MF19119; TOC Head:

$<$ jrn>Duarte, C. M., and Krause-Jensen, D. (2017). Export from seagrass meadows contributes to marine carbon sequestration. Frontiers in Marine Science 4, 13. doi:10.3389/fmars.2017.00013</jrn>

<jrn>Duarte, C. M., Kennedy, H., Marbà, N., and Hendriks, I. (2013). Assessing the capacity of seagrass meadows for carbon burial: current limitations and future strategies. Ocean and Coastal Management 83, 32-38. doi:10.1016/j.ocecoaman.2011.09.001</jrn>

$<$ conf >Gallagher, J. B. (2014). Explicit and implicit assumptions within the blue carbon conceptual model: a critique. In 'Proceedings of the International Conference on Marine Science and Aquaculture 2014: Ecosystem Perspectives in Sustainable Development', 18-20 March 2014, Kota Kinabalu, Sabah, Malaysia. (Ed. S. Mustaffa) pp. 26-40 (Universiti Malaysia Sabah). </conf >

<edb>Gallagher, J. B. (2015). The implications of global climate change and aquaculture on blue carbon sequestration and storage within submerged aquatic ecosystems. In 'Aquaculture Ecosystems'. (Eds S. Mustafa and R. Shapawi.) pp. 243-280. (Wiley Blackwell: Oxford, UK.)</edb>

$<j r n>$ Gallagher, J. B. (2017). Taking stock of mangrove and seagrass blue carbon ecosystems: a perspective for future carbon trading. Borneo Journal of Marine Science and Aquaculture 1(1), 71-74.</jrn>

$<j r n>$ Gallagher, J. B., and Ross, D. J. (2018). Sediment geochronology for bar-built estuaries subject to flood deposition and erosion: a robust multiproxy approach across an estuarine zone. The Holocene 28(3), 341353. doi:10.1177/0959683617729441</jrn>

$<$ jrn>Gallagher, J. B., Chuan, C. H., Yap, T. K., and Fredelina Dona, W. F. (2019). Carbon stocks of coastal seagrass in Southeast Asia may be far lower than anticipated when accounting for black carbon. Biology Letters 15(5), 20180745. doi:10.1098/rsbl.2018.0745</jrn>

<jrn>Gälman, V., Rydberg, J., Bindler, R., and Renberg, I. (2008). Carbon and nitrogen loss rates during aging of lake sediment: changes over 27 years studied in varved lake sediment. Limnology and Oceanography 53(3), 1076-1082. doi:10.4319/lo.2008.53.3.1076</jrn>

<jrn>Gälman, V., Rydberg, J., and Bigler, C. (2009). Decadal diagenetic effects on $\delta^{13} \mathrm{C}$ and $\delta^{15} \mathrm{~N}$ studied in varved lake sediment. Limnology and Oceanography 54(3), 917-924. doi:10.4319/lo.2009.54.3.0917</jrn>

<jrn>Gaveau, D. L. A., Salim, M. A., Hergoualc'h, K., Locatelli, B., Sloan, S., Wooster, M., Marlier, M. E., Molidena, E., Yaen, H., DeFries, R., Verchot, L., Murdiyarso, D., Nasi, R., Holmgren, P., and Sheil, D. (2015). Major atmospheric emissions from peat fires in Southeast Asia during non-drought years: evidence from the 2013 Sumatran fires. Scientific Reports 4, 6112. doi:10.1038/srep06112</jrn>

$<$ jrn>Gewert, B., Plassmann, M. M., and MacLeod, M. (2015). Pathways for degradation of plastic polymers floating in the marine environment. Environmental Science. Processes \& Impacts 17(9), 1513-1521. doi:10.1039/C5EM00207A </jrn>

$<$ jrn>Gonneea, M. E., Paytan, A., and Herrera-Silveira, J. A. (2004). Tracing organic matter sources and carbon burial in mangrove sediments over the past 160 years. Estuarine, Coastal and Shelf Science 61(2), 211-227. doi:10.1016/j.ecss.2004.04.015</jrn> 
Publisher: CSIRO; Journal: MF:Marine and Freshwater Research

Article Type: Research Paper; Volume: ; Issue: ; Article ID: MF19119

DOI: 10.1071/MF19119; TOC Head:

$<$ jrn>Gontikaki, E., Thornton, B., Cornulier, T., and Witte, U. (2015). Occurrence of priming in the degradation of lignocellulose in marine sediments. PLoS One 10(12), e0143917. doi:10.1371/journal.pone. $0143917<$ /jrn>

<jrn>Harvey, E. T., Kratzer, S., and Andersson, A. (2015). Relationships between colored dissolved organic matter and dissolved organic carbon in different coastal gradients of the Baltic Sea. Ambio 44(3), 392 401. doi:10.1007/s13280-015-0658-4</jrn>

<jrn>Hee, C. A., Pease, T. K., Alperin, M. J., and Martens, C. S. (2001). Dissolved organic carbon production and consumption in anoxic marine sediments: a pulsed-tracer experiment. Limnology and Oceanography 46(8), 1908-1920. doi:10.4319/lo.2001.46.8.1908</jrn>

<jrn>Heiri, O., Lotter, A. F., and Lemcke, G. (2001). Loss on ignition as a method for estimating organic and carbonate content in sediments: reproducibility and comparability of results. Journal of Paleolimnology 25(1), 101-110. doi:10.1023/A:1008119611481</jrn>

<jrn>Holmer, M. (1996). Composition and fate of dissolved organic carbon derived from phytoplankton detritus in coastal marine sediments. Marine Ecology Progress Series 141(1-3), 217-228. doi:10.3354/meps141217</jrn>

<jrn>Hoque, M. A., Ahad, B. G., and Saleh, E. (2010). Hydrodynamics and suspended sediment transport at tidal inlets of Salut Mengkabong Lagoon, Sabah, Malaysia. International Journal of Sediment Research. 25(4), 399-410. doi:10.1016/S1001-6279(11)60007-3</jrn>

<jrn>Howard, J. L., Creed, J. C., Aguiar, M. V. P., and Fouqurean, J. W. (2018). $\mathrm{CO}_{2}$ released by carbonate sediment production in some coastal areas may offset the benefits of seagrass 'blue carbon' storage. Limnology and Oceanography 63(1), 160-172. doi:10.1002/lno.10621</jrn>

<jrn>Johannessen, S. C., and Macdonald, R. W. (2016). Geoengineering with seagrasses: is credit due where credit is given? Environmental Research Letters 11(11), 113001. doi:10.1088/1748$\underline{9326 / 11 / 11 / 113001</ j r n>~}$

<jrn>Kaeriyama, H. (2017). Oceanic dispersion of Fukushima-derived radioactive cesium: a review. Fisheries Oceanography 26(2), 99-113. doi:10.1111/fog.12177</jrn>

<jrn>Keith, H., and Wong, S. C. (2006). Measurement of soil $\mathrm{CO}_{2}$ efflux using soda lime absorption: both quantitative and reliable. Soil Biology \& Biochemistry 38(5), 1121-1131. doi:10.1016/j.soilbio.2005.09.012</jrn>

<jrn>Kennedy, H., Beggins, J., Duarte, C. M., Fourqurean, J. W., Holmer, M., Marba, N., and Middelburg, J. J. (2010). Seagrass sediments as a global carbon sink: Isotopic constraints. Global Biogeochemical Cycles 24, GB4026. doi:10.1029/2010GB003848</jrn>

<jrn>Koelmans, A. A., and Prevo, L. (2003). Production of dissolved organic carbon in aquatic sediment suspensions. Water Research 37(9), 2217-2222. doi:10.1016/S0043-1354(02)00581-X </jrn> 
Publisher: CSIRO; Journal: MF:Marine and Freshwater Research

Article Type: Research Paper; Volume: ; Issue: ; Article ID: MF19119

DOI: 10.1071/MF19119; TOC Head:

<jrn>Koeve, W., and Kähler, P. (2010). Heterotrophic denitrification vs. autotrophic anammox: quantifying collateral effects on the oceanic carbon cycle. Biogeosciences 7(8), 2327-2337. doi:10.5194/bg-7-2327$\underline{2010}</ \mathrm{jrn}>$

<jrn>Koschorreck, M. (2008). Microbial sulphate reduction at a low pH. FEMS Microbiology Ecology 64(3), 329-342. doi:10.1111/j.1574-6941.2008.00482.x </jrn>

$<$ jrn>Kristensen, E. (1994). Decomposition of microalgae, vascular plants and sediment detritus in seawateruse of stepwise thermogravimetry. Biogeochemistry 26(1), 1-24. doi:10.1007/BF02180401</jrn>

$<$ jrn>Kristensen, E., Ahmed, S. I., and Devol, A. H. (1995). Aerobic and anaerobic decomposition of organic matter in marine sediment: which is fastest? Limnology and Oceanography 40(8), 1430-1437. doi:10.4319/lo.1995.40.8.1430</jrn>

<other>Lavelle, J. W., Massoth, G. J., and Crecelius E. A. (1985). 'Sedimentation Rates in Puget Sound from ${ }^{210} \mathrm{~Pb}$ Measurements.' NOAA technical memorandum ERL PMEL-61 (Sequim). (Pacific Marine Research Laboratory, Sequim, USA))</other>

$<j r n>$ Li, R., Zhang, L., Xue, B., and Wang, Y. (2019). Abundance and characteristics of microplastics in the mangrove sediment of the semi-enclosed Maowei Sea of the south China sea: new implications for location, rhizosphere, and sediment compositions. Environmental Pollution 244, 685-692. doi:10.1016/j.envpol.2018.10.089</jrn>

<jrn>Liang, B., Lehmann, J., Solomon, D., Sohi, S., Thies, J. E., Skjemstad, J. O., Luizão, F. J., Engelhard, M. H., Neves, E. G., and Wirick, S. (2008). Stability of biomass-derived black carbon in soils. Geochimica et Cosmochimica Acta 72, 6069-6078. doi:10.1016/j.gca.2008.09.028</jrn>

<edb>Lipton, P. (2000). Inference to the best explanation. In 'A Companion to the Philosophy of Science'. (Ed. WH Newton-Smith.) pp. 184-193. (Blackwell, Oxford (UK))</edb>

<jrn>Liu, J., Carroll, J. L., and Lerche, I. (1991). A technique for disentangling temporal source and sediment variations from radioactive isotope measurements with depth. Nuclear Geophysics 5(1-2), 3145. $<$ jrn $>$

<jrn>Marchand, C., Baltzer, F., Lallier-Vergès, E., and Albéric, P. (2004). Pore-water chemistry in mangrove sediments: relationship with species composition and developmental stages (French Guiana). Marine Geology 208(2-4), 361-381. doi:10.1016/j.margeo.2004.04.015</jrn>

$<$ jrn>Mcleod, E., Chmura, G. L., Bouillon, S., Salm, R., Björk, M., Duarte, C. M., Lovelock, C. E., Schlesinger, W. H., and Silliman, B. R. (2011). A blueprint for blue carbon: toward an improved understanding of the role of vegetated coastal habitats in sequestering $\mathrm{CO}_{2}$. Frontiers in Ecology and the Environment 9(10), 552-560. doi:10.1890/110004</jrn>

<jrn>Middelburg, J. J. (1989). A simple rate model for organic matter decomposition in marine sediments. Geochimica et Cosmochimica Acta 53(7), 1577-1581. doi:10.1016/0016-7037(89)90239-1</jrn> 
Publisher: CSIRO; Journal: MF:Marine and Freshwater Research

Article Type: Research Paper; Volume: ; Issue: ; Article ID: MF19119 DOI: 10.1071/MF19119; TOC Head:

$<$ jrn>Mostovaya, A., Hawkes, J. A., Koehler, B., Dittmar, T., and Tranvik, L. J. (2017). Emergence of the reactivity continuum of organic matter from kinetics of a multitude of individual molecular constituents. Environmental Science \& Technology 51(20), 11571-11579. doi:10.1021/acs.est.7b02876</jrn>

<jrn>Mucci, A., Sundby, B., Gehlen, M., Arakaki, T., Zhong, S., and Silverberg, N. (2000). The fate of carbon in continental shelf sediments of eastern Canada: a case study. Deep-sea Research. Part II, Topical Studies in Oceanography 47(3-4), 733-760. doi:10.1016/S0967-0645(99)00124-1</jrn>

$<$ jrn>Ni, S.-Q., and Zhang, J. (2013). Anaerobic ammonium oxidation: from laboratory to full-scale application. BioMed Research International 2013, 469360. doi:10.1155/2013/469360</jrn>

<jrn>Nor, N. H., and Obbard, J. P. (2014). Microplastics in Singapore's coastal mangrove ecosystems. Marine Pollution Bulletin 79(1-2), 278-283.</jrn>

<jrn>Pendleton, L., Donato, D. C., Murray, B. C., Crooks, S., Jenkins, W. A., Sifleet, S., Craft, C., Fourqurean, J. W., Kauffman, J. B., Marba, N., Megonigal, P., Pidgeon, E., Herr, D., Gordon, D., and Baldera, A. (2012). Estimating global ‘blue carbon' emissions from conversion and degradation of vegetated coastal ecosystems. PLoS One 7(9), e43542. doi:10.1371/journal.pone.0043542</jrn>

<jrn>Rassmann, J., Lansard, B., Pozzato, L., and Rabouille, C. (2016). Carbonate chemistry in sediment porewaters of the Rhône River delta driven by early diagenesis (northwestern Mediterranean). Biogeosciences 13(18), 5379-5394. doi:10.5194/bg-13-5379-2016</jrn>

$<$ jrn>Rillig, M. C. (2018). Microplastic disguising as soil carbon storage. Environmental Science \& Technology 52(11), 6079-6080. doi:10.1021/acs.est.8b02338</jrn>

<jrn>Salk, K. R., Erler, D. V., Eyre, B. D., Carlson-Perret, N., and Ostrom, N. E. (2017). Unexpectedly high degree of anammox and DNRA in seagrass sediments: description and application of a revised isotope pairing technique. Geochimica et Cosmochimica Acta 211, 64-78. doi:10.1016/j.gca.2017.05.012</jrn>

<jrn>Santisteban, J. I., Mediavilla, R., Lopez-Pamo, E., Dabrio, C. J., Zapata, M. B. R., Garcia, M. J. G., Castano, S., and Martinez-Alfaro, P. E. (2004). Loss on ignition: a qualitative or quantitative method for organic matter and carbonate mineral content in sediments? Journal of Paleolimnology 32(3), 287-299. doi:10.1023/B:JOPL.0000042999.30131.5b </jrn>

<jrn>Siikamäki, J., Sanchirico, J. N., Jardine, S., McLaughlin, D., and Morris, D. (2013). Blue carbon: coastal ecosystems, their carbon storage, and potential for reducing emissions. Environment 55(6), 14-29. doi:10.1080/00139157.2013.843981</jrn>

<bok>Strickland, J.D.H., and Parsons, T.R. (1968). 'A Practical Manual of Seawater Analysis.' (Queens Printer: Ottawa, ON, Canada.) $</$ bok $>$

<jrn>Tarutis, W. J. (1993). On the equivalence of the power and reactive continuum models of organic matter diagenesis. Geochimica et Cosmochimica Acta 57(6), 1349-1350. doi:10.1016/00167037(93)90071-4</jrn> 
Publisher: CSIRO; Journal: MF:Marine and Freshwater Research

Article Type: Research Paper; Volume: ; Issue: ; Article ID: MF19119

DOI: 10.1071/MF19119; TOC Head:

$<$ jrn>Wang, J., Xiong, Z., and Kuzyakov, Y. (2016). Biochar stability in soil: meta-analysis of decomposition and priming effects. Global Change Biology. Bioenergy 8(3), 512-523. doi:10.1111/gcbb.12266</jrn>

$<$ jrn>Welsh, D. T. (2000). Nitrogen fixation in seagrass meadows: regulation, plant-bacteria interactions and significance to primary productivity. Ecology Letters 3(1), 58-71. doi:10.1046/j.1461$\underline{0248.2000 .00111 . x}</ j r n>$

<jrn>Westrich, J. T., and Berner, R. B. (1984). The role of sedimentary organic matter in bacterial sulfate reduction: the G model tested. Limnology and Oceanography 29(2), 236-249. $\underline{\text { doi:10.4319/lo.1984.29.2.0236 }</ j r n>~}$

<jrn>Zimmerman, A. R., and Canuel, E. A. (2002). Sediment geochemical records of eutrophication in the mesohaline Chesapeake Bay. Limnology and Oceanography 47(4), 1084-1093. doi:10.4319/lo.2002.47.4.1084</jrn>

Handling Editor: Siti Maryam Yaakub

Fig. 1. The Salut-Mengkabong estuary site used in the study. Salut is the southern arm of the estuary, whereas Mengkabong is the lagoon situated to the North. The sites at which the seagrass sediments were obtained for the incubation experiment $(\boldsymbol{\Delta})$ and the sample cores used for SIT data $(0)$ are indicated. The seagrass distribution information is based on collective indigenous knowledge, whereas the mangrove distribution is obtained from the World Atlas of Mangroves Version 3 (Spalding et al. 2018) and from Google Earth. (Map data: Google 2019; Landsat/Copernicus, Digital Globe, Bornean Biodiversity and Ecosystems Conservation (BBEC) Sabah and WWF Malaysia 2017.) The line map was produced with QGIS v3.6.0 and Adobe Illustrator CS6.

Fig. 2. Radiogeochronological profiles down the upper seagrass sediments of Salut estuary-Mengkabong lagoon. The shaded area represents the mangrove deposition event. (a) The ${ }^{137}$ Cs activity ( $)$ down the Mengkabong meadow sediments; no activity could be detected down the Salut meadow sediments. $(b, c)$ The respective supporting ${ }^{226} \mathrm{Ra}(\bullet)$ and total ${ }^{210} \mathrm{~Pb}_{\text {total }}$ activity $(\circ) .(d, e)$ The resultant mean excess or unsupported ${ }^{210} \mathrm{~Pb}_{\text {excess }}$ activity, corrected for ${ }^{226} \mathrm{Ra}$, outside the deposition event $(\bullet)$ superimposed on their respective stable sediment isotope tomography (SIT) simulations $(\circ)$, together with $(f)$ their resultant particulate organic carbon (POC) sequestration rates for Mengkabong (०) and Salut meadows $(\bullet) .(g, h)$ Changes over time in the sedimentation and ${ }^{210} \mathrm{~Pb}_{\text {excess }}$ parameters as simulated by SIT in the Mengkabong and Salut sediment columns, with the actual recorded ${ }^{210} \mathrm{~Pb}$ excess activity $(\bullet)$ and ${ }^{210} \mathrm{~Pb}_{\text {excess }}$ activity (०) being indicated as modelled by SIT. Error bars denote the standard deviations of the counts of the radioactive decay for each horizon.

Fig. 3. Values of $\mathrm{pH}$, particulate inorganic carbon (PIC), dissolved organic carbon (DOC) and ammonia measured in the sediments throughout the incubation experiment. (a) The $\mathrm{pH}$ of the sediment slurries from Day 105 until the end of the anoxic incubation period. $(b, c)$ The PIC content of the sediment. $(d, e)$ The DOC content of the porewater of the sediment slurry. $(f, g)$ The ammonia concentrations of the porewater of the sediment slurry. Values are given for $(b, d, f)$ sediment collected from the surface 2-cm horizon and $(c, e$, 
Publisher: CSIRO; Journal: MF:Marine and Freshwater Research

Article Type: Research Paper; Volume: ; Issue: ; Article ID: MF19119

DOI: 10.1071/MF19119; TOC Head:

$704 \mathrm{~g}$ ) sediment collected from the $20-22 \mathrm{~cm}$ horizon. The last point in each series $(*)$ shows the final values of

705 the sediments after a 30-day re-oxygenation period. Error bars indicate standard errors $(n=4)$.

\begin{tabular}{lllll}
\hline Sample & $\delta^{13} \mathrm{C}(\%)$ & $\mathrm{C}(\%)$ & $\mathrm{N}(\%)$ & $\mathrm{N}: \mathrm{C}$ ratio \\
\hline \hline S0 & -24.61 & 7.83 & 0.61 & 0.066 \\
S210 & $-24.71 \pm 0.04$ & $7.64 \pm 0.13$ & $0.58 \pm 0.004$ & $0.065 \pm 0.0007$ \\
B0 & -24.06 & 7.47 & 0.62 & 0.071 \\
B210 & $-24.22 \pm 0.03$ & $7.61 \pm 0.11$ & $0.63 \pm 0.004$ & $0.070 \pm 0.0007$ \\
\hline
\end{tabular}

Fig. 4. Particulate organic matter (POC) content and loss of POC fraction of the sediments used over the anoxic incubation and subsequent re-oxygenation. The mean POC content corresponds to $(a)$ the surface 2 $\mathrm{cm}$ and $(b)$ the sediment collected from the 20-22-cm horizon. Error bars indicate the standard errors $(n=4)$. The loss of the POC fraction over time in $(c)$ the surface $2 \mathrm{~cm}$ and $(d)$ the sediment collected from the 20-22$\mathrm{cm}$ horizon, using the reactivity continuum model. Broken lines indicate the $95 \%$ confidence limit, as do the errors on the final point. The last point in each series ( ${ }^{*}$, for $a$ and $b$; $\mathbf{a}$, for $c$ and $d$ ) shows the final value of the sediments after a 30-day re-oxygenation period.

Fig. 5. Extrapolations of the fraction of remaining particulate organic carbon (POC) within the sediments over 100 years following deposition. The broken line corresponds to the sediments collected from the 20-22cm horizon, which were dated to deposition $c$. 1996, whereas the solid line corresponds to the sediments collected from the surface $2 \mathrm{~cm}$, deposited in 2016.

Fig. 6. Cumulative $\mathrm{CO}_{2}$ absorbed by soda lime and net loss of the particulate organic carbon (POC) fraction of the sediments used over the anoxic incubation. (a) The sediment was collected from the surface 2 $\mathrm{cm}$ and $(b)$ the sediment was collected from the 20-22-cm horizon. Error bars indicate the standard errors $(n$ $=4)$. The series indicated by circles $(\bullet)$ is the cumulative $\mathrm{CO}_{2}$ absorbed over the course of the incubation, whereas the series indicated by triangles (solid triangle) is the cumulative loss of POC over the same period.

\section{Table 1. Dry mass of particulate sedimentary carbon $(C)$ and stable nitrogen $(N)$ isotopes and their molar ratios from the incubation jars}

$\mathrm{S}$ and $\mathrm{B}$ refer to the surface $(0-2 \mathrm{~cm})$ and bottom $(20-22 \mathrm{~cm})$ horizons, followed by the day number during the incubation on which the sediments were extracted. All $\delta^{13} \mathrm{C}$ values have been normalised to preindustrial times (Suess effect), using their modelled depositional age. S0 and B0 are from single samples, whereas S210 and B210 are the means of four subsamples with their respective standard errors

${ }^{1}$ The $30 \%$ was calculated as the time of symmetry of the second derivative of the decay series, as percentage lost over percentage of time over a span of 100 years $(\Delta l o s t / \Delta t=1)$. Although it is a continuous function, because both scales are of the same magnitude, it, thus, marks the threshold time of a significant slowdown in decomposition. 